\title{
Loteprednol Etabonate in Ocular Inflammation
}

\author{
John Sheppard, MD, MMSc1 and Jimmy Bartlett, OD, SCD
}

\begin{abstract}
1. Professor of Ophthalmology, Microbiology, and Molecular Biology, Clinical Director, Thomas R Lee Ocular Pharmacology Center, Eastern Virginia Medical school, and President, Virginia Eye Consultants; 2. Professor and Chairman, Department of Optometry, School of Optometry, Professor of Pharmacology, Department of Pharmacology and Toxicology, School of Medicine, University of Alabama at Birmingham
\end{abstract}

\begin{abstract}
Treatment of ocular inflammation imposes a major medical and economic burden. Topical corticosteroids are effective in reducing ocular inflammation but are limited by adverse events including elevation of intraocular pressure, development of cataracts, inhibition of wound healing, and increased risk for infection or viral reactivation. Loteprednol etabonate (LE) is a unique C-20 ester corticosteroid designed to produce a predictable therapeutic effect with a low incidence of side effects. Clinical trial data have demonstrated its efficacy in a variety of ocular inflammatory conditions including giant papillary conjunctivitis, seasonal allergic conjunctivitis, anterior uveitis, superficial punctate keratitis, and dry eye syndrome. These data have been corroborated by much clinical experience. Furthermore, LE may be used to reduce the inflammation associated with ocular surgery and thus improve surgical outcomes without the risks associated with traditional ketone corticosteroid use.
\end{abstract}

\section{Keywords}

Corneal transplant, corticosteroids, superficial punctate keratitis, dry eye syndrome, giant papillary conjunctivitis, loteprednol etabonate, ocular inflammation, ocular surgery, cataract surgery, seasonal allergic conjunctivitis, anterior uveitis, intraocular pressure

Disclosure: John Sheppard, MD, MMSc, has been a consultant, lecturer, and/or has received research grants from Alcon, Allergan, Bausch \& Lomb, EyeGate Pharmaceuticals, Insite, Inspire, Isis Pharmaceuticals, Lux Biosciences, Novartis, Santen, Science Based Health, and Vistakon. Jimmy Bartlett, OD, SCD, has been a consultant, an advisory board member, and/or on the speaker's bureau of Alcon, Allergan, Bausch \& Lomb, Inspire Pharmaceuticals, ISTA Pharmaceuticals, Pfizer, Vision Service Plan, and Vistakon. Acknowledgment: Editorial assistance was provided by Touch Briefings.

Received: January 18, 2011 Accepted: March 2, 2011 Citation: US Ophthalmic Review, 2011;4(1):57-62 DOI: 10.17925/USOR.2011.04.01.57

Correspondence: Jimmy D Bartlett, OD, SCD, Department of Optometry, School of Optometry, University of Alabama at Birmingham, Birmingham, AL 35294-0010. E: eyedrug@uab.edu

Support: The publication of this article was funded by Bausch \& Lomb. The views and opinions expressed are those of the authors and not necessarily those of Bausch \& Lomb.

Ocular inflammatory diseases significantly burden patients, family members, healthcare plans, ophthalmic clinics, and workplace productivity due to health-related absenteeism. The cost of prescription medicines for ocular allergy was estimated at over $\$ 200$ million in the US in 2002, with a projected rise of $25 \%$ per year as prescription medicines continue to improve and show benefit over less efficacious over-the-counter products. ${ }^{1}$ Ocular inflammatory conditions such as seasonal allergic conjunctivitis (SAC), atopic keratoconjunctivitis (AKC), uveitis, dry eye, and routine post-operative inflammation are often treated with corticosteroids. For decades, topical corticosteroids have been used successfully to reduce the signs and symptoms of intraocular and ocular surface inflammation, providing maximal drug delivery to the local target site.

However, topical corticosteroids have been associated with side effects, e.g. increased intraocular pressure (IOP), risk for cataract formation after long-term use, decreased resistance to infection, viral reactivation, and delayed healing. ${ }^{2}$ These issues cause difficulty for ophthalmologists and optometrists treating patients with ocular inflammation for whom the provision of effective therapy is frequently a challenge.
Loteprednol etabonate (LE) is an ester corticosteroid with a welldocumented improved safety profile when compared with ketone corticosteroids, and may address some of the limitations associated with the latter for the treatment of ocular inflammatory conditions. LE is available in three formulations: LE ophthalmic suspension $0.5 \%$ (Lotemax, Bausch \& Lomb, Inc.), LE ophthalmic suspension 0.2\% (Alrex, Bausch \& Lomb, Inc.) and LE 0.5\%, and tobramycin 0.3\% ophthalmic suspension (Zylet, Bausch \& Lomb, Inc.).

\section{Incidence and Prevalence of Ocular Inflammatory Conditions}

Ocular inflammatory disease is the general term for inflammation affecting any part of the eye or adnexa. It includes a number of conditions with the common etiology of local changes in blood flow and the invasion of immune cells and inflammatory mediators. Ocular inflammation may be initiated by a variety of triggers including infection, local irritation, trauma, elective surgery, medications, environmental stress, autoimmune disorders, and chronic inflammatory disease states. The clinical spectrum of ocular inflammatory disorders ranges from 
acute conditions to chronic sight-threatening conditions and includes iatrogenic post-operative inflammation, SAC, keratoconjunctivitis sicca (dry eye syndrome), superficial punctate keratitis (SPK), AKC, giant papillary conjunctivitis (GPC), uveitis, iritis, blepharitis and scleritis. Conditions involving the lids, cornea, and conjunctiva are often termed ocular surface inflammatory disease (OSID). The signs and symptoms are typical of inflammation, including itching, pain, redness, and swelling. If left untreated, uncontrolled ocular inflammation may result in considerable ocular morbidity or even permanent loss of vision.

Ocular allergy is estimated to affect $15-20 \%$ of individuals. ${ }^{3}$ GPC is one of the most common complications of contact lens use and the prevalence is highest in soft contact lens wearers. ${ }^{4}$ Blepharitis has been reported in $37 \%$ of patients seen by ophthalmologists. ${ }^{5}$ The prevalence of dry eye has been reported to be between 7 and 33\%. ${ }^{6}$ Uveitis includes wide ranges of presentation and pathogenesis, also affecting the retina, choroid, optic nerve, iris, ciliary body, and vitreous. Uveitis-mainly posterior uveitis-is estimated to account for up to $10 \%$ of cases of blindness in the US ${ }^{7}$ and up to $25 \%$ in the developing world. ${ }^{8} \mathrm{~A}$ study in Northern California reported the incidence of uveitis to be $52.4 / 100,000$ person-years, with a period prevalence of $115.3 / 100,000$ persons. ${ }^{?}$

\section{Management Options}

The main aim of treatment for ocular inflammatory disease is to stop inflammation before permanent damage to ocular tissues and the blood aqueous barrier can occur. Corticosteroids given topically, by periocular or intravitreal injection, and orally are widely used for treating ocular inflammation. Steroids have the broadest pharmacologic impact on the plethora of mechanisms involved in ocular inflammatory events. ${ }^{10}$ Topical steroids are primarily used in clinical practice since they have the greatest bioavailability for anterior segment inflammation. ${ }^{11}$ Because they are administered directly to the surface of the eye, their effects are localized and the risk for systemic effects is minimal. ${ }^{10}$ Other treatment options include non-steroidal anti-inflammatory drugs (NSAIDS), which are widely used in allergic conjunctivitis, post-surgical analgesia, and the inflammation associated with corneal abrasion and refractive surgery. Although topical NSAIDs are associated with a low risk for undesirable side effects relative to corticosteroids, their anti-inflammatory effect is less robust. NSAIDs inhibit the production of prostaglandins but not that of other inflammatory mediators such as histamine or leukotrienes and therefore do not have a broad impact upon inflammation. Furthermore, the use of some topical NSAIDs has been associated with adverse corneal events such as burning and irritation, superficial punctate keratitis, delayed wound healing at high doses, and sterile corneal melting in the context of additional comorbidities such as OSID. ${ }^{12}$

Topical cyclosporin A is an immunosuppressant that is beneficial for topical treatment of most categories of dry eye syndrome, though its use has been associated with a burning sensation. ${ }^{13}$ Topical cyclosporin can also be used as an adjunct when other medications fail, when there is concomitant allergic inflammation, or as a steroid-sparing agent for allograft rejection prevention in stable corneal transplant patients. Another common treatment option for dry eye is artificial tears, though these do not address the underlying disease process. ${ }^{14}$ Lower-grade inflammatory conditions such as SAC may be treated with antihistamines, mast cell stabilizers, multimechanism compounds, and occasionally, decongestants. Topical antihistamines give a rapid onset of relief but a short duration of action, whereas systemic antihistamines have a longer duration of action but with a delayed onset. Furthermore, the latter may be associated with drowsiness and sometimes severe ocular drying..$^{10}$ The efficacy of mast cell stabilizers is similar to that of antihistamines though the therapeutic effect of topical mast cell stabilizers may not be as rapid. ${ }^{15}$ More recently, US Food and Drug Administration (FDA) approved lipoxygenase inhibitors such as montelukast (SingulaiR) have proven effective for allergic disease without the usual sedating and drying side effects of oral antihistamines.

\section{Mechanism of Action of Loteprednol Etabonate}

LE has the same mechanism of action as other corticosteroids. Corticosteroids inhibit the inflammatory process by decreasing the production of inflammatory precursor proteins, suppressing proliferation of important inflammatory cells, including mast cells and lymphocytes, stabilizing the extracellular membranes and mast cell granule membranes, inhibiting the production of histamine, and inhibiting the production of arachidonic acid, which is the precursor of prostaglandins and leukotrienes. However, LE has an important structural difference-the parent molecule, prednisolone, has a ketone at carbon 20 which in LE is substituted by an ester moiety. The ester component allows rapid hydrolysis to an inactive carboxylic acid metabolite. As a result, the unbound LE molecule has a short half-life, and is made inactive by endogenous esterases that are found in most human tissues. LE is therefore associated with a lower incidence of adverse effects than ketone-based steroids. ${ }^{16-19}$ Furthermore, LE has increased lipophilicity which improves penetration into cells. LE has demonstrated lipophilicity ten times greater-as well as glucocorticoidreceptor (GCR) binding affinity 4.3 times greater-than that of dexamethasone. ${ }^{20}$ LE also proved therapeutically superior to all other topical corticosteroid drops that were available at the time in a rabbit model study of lipopolysaccharide-induced uveitis. ${ }^{21}$ In this model, LE demonstrated more GCR activation and migration activity than all other drops studied, including proprietary prednisolone acetate 1\% (Pred Forte), generic $1 \%$ prednisolone acetate, and fluorometholone (FML).

\section{Clinical Utility of Loteprednol Etabonate in Ocular Inflammatory Conditions}

LE is employed in clinical practice as a first-line steroid because of its excellent safety profile $e^{3,22-25}$ and is used for virtually all anterior segment inflammatory conditions. LE is routinely used in clinical practice for acute mild-to-moderate uveitis as well as chronic long-term preventive maintenance therapy for recurrent uveitis. Other ocular surface applications include dry eye, blepharitis, non-infectious blepharitis, non-infectious conjunctivitis, and immune infiltrative keratitis, which limits contact lens wear and comfort. Treatment enables patients to return to wearing contact lenses sooner than would be possible with other drugs. To avoid rebound inflammation, it is typically necessary to taper ketone-based steroids, but because unbound LE is metabolized so quickly, aggressive tapering is generally not required. In fact, in almost all of the clinical trials utilizing LE prior to regulatory approvals, treatment was stopped without tapering and no rebound effects were observed. Numerous clinical studies have demonstrated the efficacy of LE (see Table 1). In clinical studies, LE demonstrated a rapid therapeutic response in the treatment of GPC with a low incidence 
Table 1: Summary of Clinical Trials on Efficacy of Loteprednol Etabonate

\begin{tabular}{|c|c|c|c|c|c|}
\hline Phase/Study/Design & No. Patients & Treatments & End-points & Efficacy Findings & Safety Findings \\
\hline SAC, phase III trial ${ }^{26}$ & 133 & $\begin{array}{l}\text { LE } 0.2 \%, 4 x / \text { day, } \\
42 \text { days }\end{array}$ & $\begin{array}{l}\text { Reductions in bulbar conjunctival } \\
\text { injection and itching at two weeks }\end{array}$ & $\begin{array}{l}\text { Reduction in bulbar } \\
\text { conjunctival injection of } 1.3 \text { units } \\
\text { on zero to three point scale } \\
\text { versus } 0.9 \text { vehicle }(p<0.001) \text {. } \\
\text { Itching reduction } 3.5 \text { units } \\
\text { versus } 3.1 \text { units vehicle }(p=0.001)\end{array}$ & $\begin{array}{l}\text { No serious or } \\
\text { unexpected } \\
\text { adverse effects }\end{array}$ \\
\hline $\begin{array}{l}\text { Allergic conjunctivitis, } \\
\text { double-masked } \\
\text { crossover study }^{27}\end{array}$ & 60 & $\begin{array}{l}\text { LE } 0.2 \% \text {, versus, } \\
\text { olopatadine, } 0.1 \% \text {, } \\
2 x / \text { day, } 35 \text { days }\end{array}$ & $\begin{array}{l}\text { OSDI score, global self-assessment } \\
\text { of drug tolerability }\end{array}$ & $\begin{array}{l}55 \% \text { reduction in OSDI score } \\
\text { in LE group versus } 26 \% \\
\text { reduction in olopatadine group }\end{array}$ & $\begin{array}{l}\text { Less than one on scale } \\
\text { of zero to four for } \\
\text { frequency of stinging, } \\
\text { blurry vision and redness }\end{array}$ \\
\hline $\begin{array}{l}\text { Prophylaxis of SAC. } \\
\text { Prospective multicenter } \\
\text { randomized } \\
\text { placebo-controlled } \\
\text { parallel study }{ }^{23}\end{array}$ & 293 & $\begin{array}{l}\text { LE } 0.5 \% \text { versus vehicle, } \\
4 x / \text { day, } 42 \text { days }\end{array}$ & $\begin{array}{l}\text { Absence of moderate or worse } \\
\text { signs or symptoms of ocular allergy } \\
\text { during peak pollen period. } \\
\text { Composite scores for itching and } \\
\text { bulbar injection }\end{array}$ & $\begin{array}{l}\text { 94\% LE group achieved } \\
\text { prophylactic efficiency } \\
\text { versus } 78 \% \text { vehicle } \\
\text { group ( } p=0.001 \text { ) }\end{array}$ & $\begin{array}{l}\text { No increase of IOP } \\
\text { of } 10 \mathrm{mmHg} \text { or greater }\end{array}$ \\
\hline $\begin{array}{l}\text { Post-operative } \\
\text { inflammation, double- } \\
\text { masked } \\
\text { placebo-controlled }{ }^{3}\end{array}$ & 227 & $\begin{array}{l}\text { LE } 0.5 \% \text { versus vehicle, } \\
14 \text { days after } \\
\text { surgery, } 4 x / \text { day }\end{array}$ & $\begin{array}{l}\text { Resolution of anterior chamber } \\
\text { inflammation at final } \\
\text { treatment visit }\end{array}$ & $\begin{array}{l}\text { Resolution in } 64 \% \text { of LE group } \\
\text { and } 29 \% \text { of vehicle } \\
\text { group ( } p<0.001)\end{array}$ & $\begin{array}{l}\text { Little evidence of IOP } \\
\text { elevation or } \\
\text { deleterious effects }\end{array}$ \\
\hline $\begin{array}{l}\text { Post-operative } \\
\text { inflammation, double- } \\
\text { masked placebo-controlled }{ }^{28}\end{array}$ & 203 & $\begin{array}{l}\text { LE } 0.5 \% \text { versus placebo, } \\
14 \text { days after } \\
\text { surgery, } 4 x / \text { day }\end{array}$ & $\begin{array}{l}\text { Resolution of anterior chamber } \\
\text { inflammation at final } \\
\text { treatment visit }\end{array}$ & $\begin{array}{l}\text { Resolution in } 55 \% \text { of LE } \\
\text { group versus } 28 \% \text { in vehicle } \\
\text { group }(p<0.001)\end{array}$ & $\begin{array}{l}\text { No IOP elevation of } \\
10 \mathrm{mmHg} \text { or more }\end{array}$ \\
\hline $\begin{array}{l}\text { Acute anterior } \\
\text { uveitis study } 1^{16}\end{array}$ & 70 & $\begin{array}{l}\text { LE } 0.5 \% \text { versus } \\
\text { prednisolone actetate, } \\
42 \text { days, } 8 \text { x/day }\end{array}$ & $\begin{array}{l}\text { Resolution of anterior chamber } \\
\text { inflammation at final } \\
\text { treatment visit }\end{array}$ & $\begin{array}{l}\text { Resolution in } 74 \% \text { LE } \\
\text { group versus } 88 \% \text { PA group }\end{array}$ & $\begin{array}{l}\text { IOP increases } \\
\geq 10 \mathrm{mmHg} \text { more } \\
\text { frequent in PA than } \\
\text { LE group }\end{array}$ \\
\hline $\begin{array}{l}\text { Acute anterior } \\
\text { uveitis study } 2^{16}\end{array}$ & 175 & $\begin{array}{l}\text { LE } 0.5 \% \text { versus } \\
\text { prednisolone actetate, } \\
28 \text { days } 16 x \text { /day }\end{array}$ & $\begin{array}{l}\text { Resolution of anterior chamber } \\
\text { inflammation at final } \\
\text { treatment visit }\end{array}$ & $\begin{array}{l}\text { Resolution in } 72 \% \text { LE group } \\
\text { versus } 87 \% \text { PA group }\end{array}$ & $\begin{array}{l}\text { IOP increases } \\
\geq 10 \mathrm{~mm} \text { Hg more } \\
\text { frequent in PA than } \\
\text { LE group }\end{array}$ \\
\hline $\begin{array}{l}\text { GPC prospective } \\
\text { multicenter } \\
\text { double-masked } \\
\text { parallel-group study }{ }^{29}\end{array}$ & 110 & $\begin{array}{l}\text { LE } 0.5 \% \text { versus vehicle, } \\
28 \text { days, } 4 x / \text { days }\end{array}$ & Papillae rated scale zero to three & $\begin{array}{l}57 \% \text { of LE group mild papillae } \\
\text { by } 28 \text { days, } 16 \% \text { free of } \\
\text { papillae versus } 2 \% \text { free of } \\
\text { papillae in vehicle group }\end{array}$ & No changes in IOP \\
\hline $\begin{array}{l}\text { GPC randomized } \\
\text { double-masked } \\
\text { parallel-group study }\end{array}$ & 223 & $\begin{array}{l}\text { LE } 0.5 \% \text { versus vehicle, } \\
42 \text { days, } 4 x / \text { day }\end{array}$ & $\begin{array}{l}\text { Improvement of at least one grade } \\
\text { at final visit in papillae, itching and } \\
\text { lens intolerance }\end{array}$ & $\begin{array}{l}\text { Improvement in papillae } 78 \% \text { of } \\
\text { LE group versus } 51 \% \text { vehicle } \\
(p<0.001) . \text { Improvement in itching } \\
95 \% \text { versus } 81 \%(p<0.001) \text {. } \\
\text { Improvement in lens tolerance } \\
87 \% \text { versus } 77 \%(p=0.053)\end{array}$ & $\begin{array}{l}\text { Both well tolerated, } \\
\text { no serious or } \\
\text { unexpected } \\
\text { treatment-related events }\end{array}$ \\
\hline $\begin{array}{l}\text { GPC randomized } \\
\text { double-masked } \\
\text { parallel-group study }{ }^{22}\end{array}$ & 220 & $\begin{array}{l}\text { LE } 0.5 \% \text { versus vehicle, } \\
42 \text { days, } 4 x / \text { day }\end{array}$ & $\begin{array}{l}\text { Improvement of at least one grade } \\
\text { at final visit in papillae, itching and } \\
\text { lens tolerance }\end{array}$ & $\begin{array}{l}\text { Improvement in papillae } 75 \% \\
\text { of LE group versus } 50 \% \text { vehicle } \\
(p<0.001) . \text { Improvement in itching } \\
92 \% \text { versus } 76 \% \text { ( } p=0.001) \text {. } \\
\text { Improvement in lens tolerance } \\
84 \% \text { versus } 66 \% \text { ( } p=0.002)\end{array}$ & $\begin{array}{l}\text { Both well tolerated, no } \\
\text { serious or unexpected } \\
\text { treatment-related events }\end{array}$ \\
\hline $\begin{array}{l}\text { Dry eye with delayed } \\
\text { tear clearance, } \\
\text { multicenter randomized } \\
\text { placebo-controlled study }{ }^{31}\end{array}$ & 66 & $\begin{array}{l}\text { LE } 0.5 \% \text { versus vehicle, } \\
28 \text { days, } 4 x / \text { day }\end{array}$ & $\begin{array}{l}\text { Combined corneal staining score, } \\
\text { biomicroscopy findings }\end{array}$ & $\begin{array}{l}\text { Statistically significant } \\
\text { improvement in both groups } \\
\text { in primary variable ( } p<0.0001) \text {. } \\
\text { LE group showed significant } \\
\text { improvement in nasal bulbar } \\
\text { conjunctival injection ( } P=0.0431 \text { ) }\end{array}$ & $\begin{array}{l}\text { No significant rise in } \\
\text { IOP or treatment- } \\
\text { related events }\end{array}$ \\
\hline
\end{tabular}

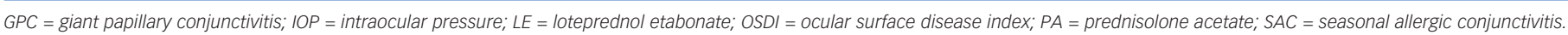

of IOP elevation (see Figure 1). 17,22,30 The efficacy of LE has also been demonstrated in the prophylactic treatment of SAC when administered six weeks before the onset of the allergy season. ${ }^{23}$
A study assessing the efficacy of LE in acute anterior uveitis found significant reductions in symptoms in the LE treatment group, although LE was less effective overall than prednisolone acetate 
Figure 1: Proportion of Patients Treated for Giant Papillary Conjunctivitis with Loteprednol Etabonate versus Placebo with a Decrease in Severity of at least One Unit in Papillae, Itching, and Lens Intolerance

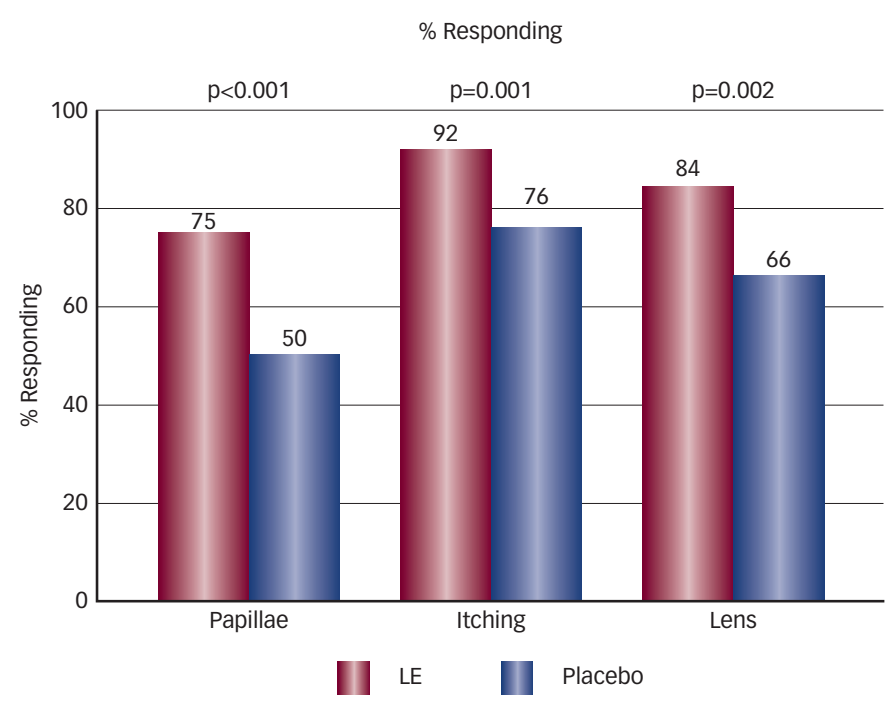

$L E=$ loteprednol etabonate. Source: Asbell and Howes, 1997.22

(PA) due to asymmetric treatment group patient drop-outs and last-observation-carried-forward (LOCF) statistical analysis. However, the PA-treated group had a significantly higher incidence of elevated IOP compared with the LE-treated group. ${ }^{16}$ A recent study comparing $\mathrm{LE}$, dexamethasone sodium phosphate, fluorometholone, and PA in the reduction of uveitis in rabbits concluded that LE was consistently the most clinically effective across several parameters, and was one of only two effective agents. ${ }^{21}$ The clinical efficacy of LE has also been demonstrated in the treatment of dry eye in patients with delayed tear clearance. In patients with moderate or severe inflammation, there was a significant difference between LE and placebo groups after two weeks of treatment. ${ }^{31}$ LE has also proved useful as an adjunctive therapy to topical cyclosporine A emulsion (Restasis, Allergan), accelerating resolution of symptoms and reducing the potential stinging irritation seen in $17 \%$ of patients using topical cyclosporine $A^{32}$

A topical combination of LE (0.5\%) and tobramycin (Zylet, $0.3 \%$ ) is indicated for the treatment of steroid-responsive ocular inflammatory conditions in which there exists either superficial bacterial ocular infection or a potential risk for bacterial infection. The combination product has been found to be superior to dexamethasone/tobramycin in healthy subjects in terms of comfort and tolerability. ${ }^{33}$ Furthermore, healthy subjects treated with this combination had smaller increases in IOP than those treated with dexamethasone and tobramycin. ${ }^{34}$ zylet has been demonstrated to be as effective as dexamethasone and tobramycin in the treatment of ocular inflammation associated with blepharokeratoconjunctivitis. ${ }^{35}$

\section{Clinical Experience with and Ongoing Studies of Loteprednol Etabonate} Long-term Management of Corneal Transplant Patients Anti-inflammatory agents play a central role in the long-term management of penetrating keratoplasty (corneal transplant) patients, since corneal allograft rejection is the major cause of graft failure. ${ }^{36}$ The risks and expense of topical steroid maintenance therapy to prevent graft rejection are small compared to the costs, potential surgical complications, and significant personal inconveniences to patients who require a repeat allograft. Topical corticosteroids have been the mainstay of allograft rejection strategies, yet the associated risks of elevated IOP can potentially damage the endothelium or optic nerve of post-operative patients. ${ }^{37}$ Corneal transplant patients switching from post-operative PA to LE experienced a reduction in IOP of $32.6 \%$ at three weeks and $44.9 \%$ at 39 weeks. ${ }^{38}$

The maintenance steroid dosage varies widely between corneal transplant patients, largely due to highly variable rejection risk profiles. Infants and children have a significantly higher risk for allograft rejection, as do those with concomitant ocular surface disease, glaucoma or previous ocular surgery, previous transplants, previous rejection reactions or full-blown irreversible rejection, corneal neovascularization, systemic inflammatory conditions, ocular herpes simplex, ocular inflammatory conditions such as uveitis, a history of ocular trauma, or undetected loose corneal sutures. A lower risk for rejection is seen in older patients, patients without other ocular conditions, patients who have isolated endothelial dystrophies, patients who undergo Descemet's stripping endothelial keratoplasty (DSEK)—which only replaces the innermost corneal layer, rather than penetrating keratoplasty-and those who are otherwise healthy.

The maintenance dose for allograft rejection should be matched to the risk status of each individual patient. The ideal treatment aim is a oncedaily dose of LE, which can be achieved frequently in the lower-risk categories. However, higher-risk patients may require more frequent dosages. Because of the lower-risk for IOP elevation associated with LE and the generally higher risk for developing glaucoma in the transplant population, LE is a valuable component in long-term rejection prophylaxis strategies.

\section{Loteprednol Etabonate in Post-operative Inflammation}

A degree of post-operative ocular inflammation is an inevitable consequence of even the most uneventful cataract surgery. ${ }^{39}$ This can result in iritis and/or cystoid macular edema (CME).$^{40} \mathrm{CME}$ is the most frequent cause of compromised visual acuity following uncomplicated cataract surgery and often has a late onset of up to four to six weeks, post-operatively. A recent review found an overall CME incidence of $1.95 \%$ of those undergoing cataract surgery and that CME is associated with substantial costs. ${ }^{41}$ The incidence of CME is much higher in higher-risk cataract patients, such as those with diabetes, pre-existing macular disease, transplants, iritis, complicated or multiple procedures, and patients with previous ocular surgery or trauma.

A number of studies have demonstrated the efficacy of LE in cataract surgery. LE was found to give a clinically meaningful reduction in the signs and symptoms of post-operative anterior chamber inflammation following cataract surgery (see Table 1). ${ }^{3,30}$ This was also demonstrated by a post hoc analysis of two double-masked, vehicle-controlled, multicenter studies that evaluated the effect of loteprednol $(n=211)$ compared with vehicle alone $(n=213)$ on pain, photophobia, itching, tearing, dryness, discharge, and discomfort in patients who had 
undergone cataract surgery with IOL implantation.42 The results of both studies showed significant treatment effects on pain, photobia, tearing, and pain. Pooled results showed that the proportions of at-risk subjects with resolution of pain or discomfort were significantly greater in the groups who received loteprednol than in those who received vehicle alone.

\section{Combination Therapy with Non-steroidal}

\section{Anti-inflammatory Drugs}

NSAIDS are an important component of the post-operative management of refractive and cataract surgery due to their analgesic and anti-inflammatory effects. LE and other topical steroids act synergistically in combination with NSAIDS, since their mechanism of action differs from that of NSAIDS. NSAIDS primarily act on the cyclooxygenase (COX-1 and COX-2) pathway, minimizing prostaglandin formation, whereas steroids primarily act on phospholipase A2, inhibiting the release of arachidonic acid. In general, cataract surgeons use a combination of anti-inflammatory agents as part of their post-operative regimens and a combination of steroids and NSAIDS has been found to be more effective than steroids alone. ${ }^{40} \mathrm{~A}$ prospective trial found that combination therapy of prednisolone and ketorolac is more beneficial than monotherapy with either agent in the prevention of CME. ${ }^{43}$ Although no published studies echo this synergy between NSAIDs and LE, it stands to reason that such synergies are expected and many surgeons combine these two agents following routine or complicated cataract surgery.

\section{Long-term Use of Loteprednol Etabonate and the Impact on Intraocular Pressure}

The impact of LE on IOP is minimal compared to other topical corticosteroids. Long-term use of LE results in clinically significant (10 $\mathrm{mmHg}$ or greater) elevations of IOP in only a small fraction of cases. A study evaluating all patients participating in LE studies found that only $1.7 \%$ of those receiving LE for 28 days or longer had clinically significant elevations of IOP compared with $6.7 \%$ of those taking PA. In patients not wearing contact lenses or those taking LE $0.2 \%$, the incidence was reduced to 0.6 and $0.8 \%$, respectively, which was remarkably similar to placebo (see Figure 2). ${ }^{25}$ In another study, over a 43-day period, statistically and clinically significant IOP elevations were observed in known steroid responders treated with PA, whereas the IOP changes observed in those taking LE $0.5 \%$ were neither clinically nor statistically significant. ${ }^{17}$ These data are consistent with observations in clinical practice. A retrospective review of 397 seasonal and perennial allergic conjunctivitis patients who had been prescribed LE $0.2 \%$ at least once a day for one to four years recorded no steroid-induced adverse effects. No patient developed increased IOP greater than $4 \mathrm{mmHg}$ above baseline. ${ }^{44}$

As with the use of any steroid, careful patient selection and monitoring is important. Glaucoma patients almost always experience rises in IOP following the application of topical steroids, so monitoring over a few weeks is essential. If an increase is observed, the steroid should be tapered or stopped if possible. If continued steroid therapy is necessary, an ocular hypotensive medication should be given in conjunction with the steroid to reduce the IOP, for example a beta-blocker or alpha-2 agonist such as brimonidine. Selective laser
Figure 2: Incidence of Significant Elevations in Intraocular Pressure $(10 \mathrm{mmHg}$ or More) in Patients Treated with Loteprednol Etabonate versus Prednisolone Acetate

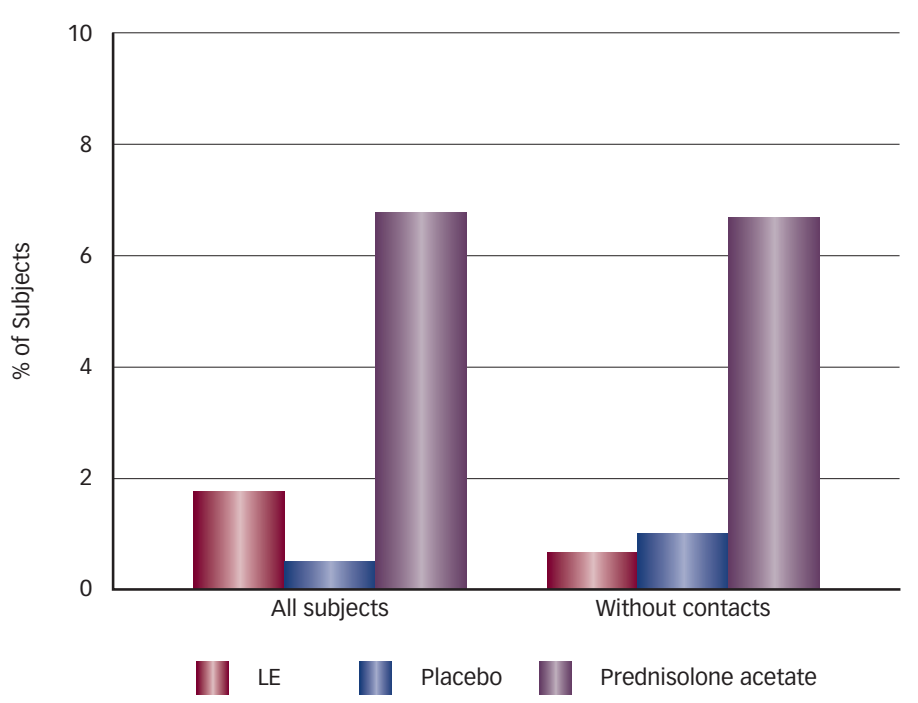

$L E=$ loteprednol etabonate. Source: Novack et al., 1998. ${ }^{25}$

trabeculoplasty (SLT) is also a useful adjunct to topical steroids in patients with mild IOP elevations.

\section{Long-term Safety of Loteprednol Etabonate}

Numerous studies have found that LE is well tolerated with no serious treatment-related adverse events ${ }^{44}$ (see Table 1). After six weeks of treatment with $0.5 \% \mathrm{LE}$, no evidence of systemic absorption of LE or its metabolite PF-71 was observed, nor was there any evidence of adrenal suppression. ${ }^{45}$ Furthermore, although corticosteroids are associated with cataracts and diminished immune responses, there are no published cases or reports of LE-induced cataracts. The longterm safety of LE makes it an excellent choice for long-term maintenance therapy. LE is contraindicated in patients with ocular infections due to Acanthamoeba, herpes simplex virus, and fungi.

\section{Conclusion}

LE has demonstrated efficacy in clinical studies in a variety of ocular inflammatory conditions and a wealth of evidence supports its use as first-line therapy in clinical practice. It combines the efficacy of PA with a favorable reduction in side effects. Its rapid metabolism makes it safe for the treatment of corneal, ocular surface, and intraocular inflammation. Its applications in induction as well as in maintenance therapy_targeting a wide variety of conditions-make it a versatile treatment option. LE is an ideal medication for the patient requiring prolonged or even lifelong anti-inflammatory therapy, including patients with uveitis, corneal transplantation, previous trauma, glaucoma shunts, or chronic ocular surface disease. In addition, LE can play an integral role in the management of patients who have undergone ocular surgery. LE helps to optimize surgical outcomes through the minimization of inflammationrelated post-operative complications and the risk for steroid-related side effects. The development of modified corticosteroids has far-reaching implications for the treatment of inflammatory eye disease and merits continued evaluation in clinical trials to further define the clinical utility of LE and other modified corticosteroids. 
1. Bielory L, Update on ocular allergy treatment, Expert Opin Pharmacother, 2002:3:541-53.

2. MCGhee CN, Dean S, Danesh-Meyer H, Locally administered ocular corticosteroids: benefits and risks, Drug Saf, 2002;25:33-55

3. Stewart R, Horwitz B, Howes J, et al., Double-masked, placebocontrolled evaluation of loteprednol etabonate $0.5 \%$ for postoperative inflammation. Loteprednol Etabonate Postoperative Inflammation Study Group 1, I Cataract Refract Surg 1998:24:1480-9.

4. Forister JF, Forister EF, Yeung KK, et al., Prevalence of contact lens-related complications: UCLA contact lens study, Eye Contact Lens, 2009;35:176-80.

5. Lemp MA, Nichols KK, Blepharitis in the United States 2009: a survey-based perspective on prevalence and treatment, Ocul Surf, 2009;7:S1-S14.

6. Gayton JL, Etiology, prevalence, and treatment of dry eye disease, Clin Ophthalmol, 2009;3:405-12.

7. Suttorp-Schulten MS, Rothova A, The possible impact of uveitis in blindness: a literature survey, Br I Ophthalmol, 1996;80:844-8.

8. London NJ, Rathinam SR, Cunningham ET, Jr., The epidemiology of uveitis in developing countries, Int Ophthalmol Clin, 2010;50:1-17.

9. Gritz DC, Wong IG, Incidence and prevalence of uveitis in Northern California; the Northern California Epidemiology of Uveitis Study, Ophthalmology, 2004;111:491-500.

10. Pavesio CE, Decory $\mathrm{HH}$, Treatment of ocular inflammatory conditions with loteprednol etabonate, Br J Ophthalmol, 2008;92:455-9.

11. Jaanus SD, Drug therapy for ocular allergy, Optom Clin 1992;2:35-44

12. Congdon NG, Schein OD, von Kulajta $P$, et al., Corneal complications associated with topical ophthalmic use of nonsteroidal antiinflammatory drugs, I Cataract Refract surg 2001;27:622-31.

13. Perry HD, Solomon R, Donnenfeld ED, et al., Evaluation of topical cyclosporine for the treatment of dry eye disease, Arch Ophthalmol, 2008;126:1046-50

14. O'Brien PD, Collum LM, Dry eye: diagnosis and current treatment strategies, Curr Allergy Asthma Rep, 2004:4:314-9.

15. Owen CG, Shah A, Henshaw K, et al., Topical treatments for seasonal allergic conjunctivitis: systematic review and meta-analysis of efficacy and effectiveness, $\mathrm{Br} J$ Gen Pract, 2004;54:451-6.

16. Loteprednol Etabonate US Uveitis Study Group, Controlled evaluation of loteprednol etabonate and prednisolone acetate in the treatment of acute anterior uveitis, Am I Ophthalmol 1999:537-44

17. Bartlett JD, Horwitz B, Laibovitz R, et al., Intraocular pressure response to loteprednol etabonate in known steroid responders, J Ocul Pharmacol, 1993;9:157-65.

18. Bucala R, Gallati M, Manabe S, et al., Glucocorticoid-lens protein adducts in experimentally induced steroid cataracts, Exp Eye Res, 1985;40:853-63.
19. Manabe $S$, Bucala R, Cerami A, Nonenzymatic addition of glucocorticoids to lens proteins in steroid-induced cataracts, J Clin Invest, 1984;74:1803-10.

20. Druzgala P, Hochhaus G, Bodor N, Soft drugs--10. Blanching activity and receptor binding affinity of a new type of glucocorticoid: loteprednol etabonate, I Steroid Biochem Mol Biol, 1991:38:149-54.

21. Samudre SS, Lattanzio FA, Jr., Williams PB, et al., Comparison of topical steroids for acute anterior uveitis, I Ocul Pharmacol Ther, 2004;20:533-47.

22. Asbell P, Howes J, A double-masked, placebo-controlled evaluation of the efficacy and safety of loteprednol etabonate in the treatment of giant papillary conjunctivitis, CLAO J, 1997:23:31-6.

23. Dell SJ, Shulman DG, Lowry GM, et al., A controlled evaluation of the efficacy and safety of loteprednol etabonate in the prophylactic treatment of seasonal allergic conjunctivitis. Loteprednol Allergic Conjunctivitis Study Group, Am I Ophthalmol, 1997;123:791-7.

24. Neumann R, Howes JF, Loteprednol etabonate: a novel ocular steroid with improved safety profile. In: Nussenblatt RB, Whitcup SM, Caspi RM, Gery I (eds.), Advances in Ocular Immunology: Proceedings of the 6th International Symposium on the Immunology and Immunopathology of the Eye, New York: Elsevier, 1994;245-8.

25. Novack GD, Howes J, Crockett RS, et al., Change in intraocular pressure during long-term use of loteprednol etabonate, $J$ Glaucoma, 1998; 7:266-9.

26. Dell SJ, Lowry GM, Northcutt JA, et al., A randomized, doublemasked, placebo-controlled parallel study of $0.2 \%$ lotepredno etabonate in patients with seasonal allergic conjunctivitis, J Allergy Clin Immunol, 1998:102:251-5.

27. KoO EH, Samudre SS, Williams PB, et al, Loteprednol etabonate ophthalmic suspension $0.2 \%$ and olopatadine hydrochloride ophthalmic solution $0.1 \%$ in the treatment of allergic conjunctivitis, Invest Ophthalmol Vis Sci, 2008;49:Abstract 422.

28. The Loteprednol Etabonate Postoperative Inflammation Study Group 2, A double-masked, placebo-controlled evaluation of $0.5 \%$ loteprednol etabonate in the treatment of postoperative inflammation. The Loteprednol Etabonate Postoperative Inflammation Study Group 2, Ophthalmology, 1998;105(9):1780-6

29. Bartlett JD, Howes JF, Ghormley NR, et al., Safety and efficacy of loteprednol etabonate for treatment of papillae in contact lens-associated giant papillary conjunctivitis, Curr Eye Res, 1993;12:313-21.

30. Friedlaender $\mathrm{MH}$, Howes J, A double-masked, placebo-controlled evaluation of the efficacy and safety of loteprednol etabonate in the treatment of giant papillary conjunctivitis. The Loteprednol Etabonate Giant Papillary Conjunctivitis Study Group I, Am I Ophthalmol, 1997:123:455-64.

31. Pflugfelder SC, Maskin SL, Anderson B, et al., A randomized, double-masked, placebo-controlled, multicenter comparison of loteprednol etabonate ophthalmic suspension, $0.5 \%$, and placebo for treatment of keratoconjunctivitis sicca in patients with delayed tear clearance, Am I Ophthalmol, 2004;138:444-57.

32. Sheppard JD, Scoper SV, Samudre S, Topical loteprednol pretreatment reduces cyclosporine stinging in chronic dry eye disease, I Ocul Pharmacol Ther, 2011:27(1):23-7.

33. Bartlett JD, Holland EJ, Usner DW, et al., Tolerability of loteprednol/tobramycin versus dexamethasone/tobramycin in healthy volunteers: results of a 4-week, randomized, double-masked, parallel-group study, Curr Med Res Opin, 2008;24:2219-27.

34. Holland EJ, Bartlett JD, Paterno MR, et al., Effects of loteprednol/tobramycin versus dexamethasone/tobramycin on intraocular pressure in healthy volunteers, cornea, 2008;27:50-5.

35. White EM, Macy JI, Bateman KM, et al., Comparison of the safety and efficacy of loteprednol $0.5 \% /$ tobramycin $0.3 \%$ with dexamethasone $0.1 \% /$ tobramycin $0.3 \%$ in the treatment of blepharokeratoconjunctivitis, Curr Med Res Opin, 2008;24:287-96.

36. Panda $A$, Vanathi $M$, Kumar $A$, et al., Corneal graft rejection, Surv Ophthalmol, 2007:52:375-96.

37. Charlin R, Polack FM, The effect of elevated intraocular pressure on the endothelium of corneal grafts, cornea, 1982;1:241-9.

38. Holland EJ, Djalilian AR, Sanderson JP, Attenuation of ocular hypertension with the use of topical loteprednol etabonate $0.5 \%$ in steroid responders after corneal transplantation, Cornea, 2009;28:1139-43.

39. Mohammadpour M, Jafarinasab MR, Javadi MA, Outcomes of acute postoperative inflammation after cataract surgery, Eur I Ophthalmol, 2007;17:20-8.

40. Henderson BA, Kim JY, Ament CS, et al., Clinical pseudophakic cystoid macular edema. Risk factors for development and duration after treatment, I Cataract Refract Surg, 2007;33:1550-8.

41. Schmier JK, Halpern MT, Covert DW, et al., Evaluation of costs for cystoid macular edema among patients after cataract surgery, Retina, 2007;27:621-8.

42. Comstock TL, Usner DL, Effect of Loteprednol Etabonate Ophthalmic Suspension $0.5 \%$ on Post-Operative Pain and Discomfort. Poster presented at the American Society of Cataract and Refractive Surgery Annual Symposium, Boston Massachusetts, April 9-14, 2010

43. Heier JS, Topping TM, Baumann W, et al., Ketorolac versus prednisolone versus combination therapy in the treatment of acute pseudophakic cystoid macular edema, Ophthalmology . 2000:107:2034-8.

44. Ilyas $H$, Slonim CB, Braswell GR, et al., Long-term safety of loteprednol etabonate $0.2 \%$ in the treatment of seasonal and perennial allergic conjunctivitis, Eye Contact Lens, 2004;30:10-3.

45. Howes J, Novack GD, Failure to detect systemic levels, and effects of loteprednol etabonate and its metabolite, PJ-91, following chronic ocular administration, J ocul Pharmacol Ther, 1998:14:153-8. 